\title{
RESENHA
}

\section{O Princípio Pluralista}

\author{
The PluRalist PRINCiple
}

\author{
El Principio Pluralista
}

\section{Ana Ester Pádua Freire*}

RIBEIRO, Claudio de Oliveira. O princípio pluralista. São Paulo: Loyola, 2020. 480 p.

O princípio pluralista, tal como proposto por Claudio Ribeiro nesta obra, pode ser compreendido como um giro. Um giro decolonial metodológico, religioso e antropológico. Segundo diferentes autores e autoras, giro decolonial é um termo cunhado no contexto das discussões sobre modernidade e colonialidade como sendo um movimento de resistência à lógica colonial. Há uma intenção aberta em decolonizar o poder, o saber e o ser por meio não somente do reconhecimento das estratégias de controle da colonialidade, mas também por meio da proposta de saídas, de escapes desse regime colonial de regulação da vida, dos corpos e dos afetos.

Um giro tem a capacidade de transitar em diferentes lugares, por isso, nesta resenha, pretende-se apresentar a obra a partir de suas contribuições para uma discussão sobre dissidências sexuais e de gênero. Uma definição que nos interessa mais de perto é de que o princípio pluralista "[...] se constitui em instrumento de avaliação da realidade social e cultural, sobretudo para melhor compreensão das diferenças, religiosas ou não, que se forjam nos entre-lugares das culturas.” (RIBEIRO, 2020, p. 30). O que a citação nos apresenta é o princípio pluralista como sendo uma perspectiva de análise da realidade que parte do reconhecimento das diferenças. Nesse sentido, seria possível comparar o princípio pluralista a lentes de óculos que permitem que o mundo e toda a sua complexidade seja visto de maneira diferente. A ideia de olhar, de mirada, é muito típica da proposta

\footnotetext{
* Doutora e mestra em Ciências da Religião pela Pontifícia Universidade Católica de Minas Gerais. Brasil. ORCID: 0000-0001-5188-1520. E-mail: anaesterbh@gmail.com.
} 
hermenêutica da teologia latino-americana, à qual Claudio Ribeiro de alguma forma se afilia. As lentes da libertação, do feminismo, da raça, de classe, são algumas das hermenêuticas possíveis da teologia latino-americana. Entretanto, o princípio pluralista parece ser, em primeiro lugar, uma lente anterior a todas essas, ou seja, uma lente que permite todas essas possibilidades interpretativas. E, em segundo lugar, uma lente posterior a todas essas, ou seja, uma lente que requer que as perspectivas hermenêuticas, ainda que se pretendam libertárias, se abram para o novo, percebendo no pluralismo a lente para uma vida em constante transformação.

Segundo Ribeiro (2020), a perspectiva pluralista das religiões evoca questões no contexto teológico latino-americano, “[...] especialmente pela sua vocação libertadora e pelos desafios que advêm de sua composição cultural fortemente marcada por diferenças religiosas que se interpenetram nas mais diferentes formas." (RIBEIRO, 2020, p. 21). A partir dessa afirmação, talvez seja possível sugerir que mais do que uma lente anterior ou posterior, o princípio pluralista seja um caleidoscópio, uma lente repleta de diferentes cores e formas, que nos abre ao inesperado que nos é exposto pelas diferenças.

Nos interessa muito perceber como o princípio pluralista não se advoga totalizador, universalista ou essencialista. Pelo contrário, é um princípio que percebe suas limitações e seus desafios diante da complexidade da realidade. Segundo Ribeiro (2020), o princípio pluralista tem pelo menos três desafios em sua aplicação referentes ao método, ao quadro religioso e às questões de natureza antropológica. De acordo com autor, "[...] o primeiro deles é a tarefa de alargamento metodológico e de atualização nas formas de compreensão da realidade, pressuposto sempre presente nas teologias de caráter social e político." (RIBEIRO, 2020, p. 22). Já o segundo "[...] está em torno das questões relativas à emergência das subjetividades na atualidade." (RIBEIRO, 2020, p. 22). Por fim, “[...] um terceiro desafio reside em torno dos encontros e desencontros da teologia com a pluralidade." (RIBEIRO, 2020, p. 22).

Em alguma medida, em se tratando de dissidências sexuais e de gênero, os três desafios atravessam o debate. O metodológico porque prevê não somente um alargamento metodológico, mas uma erotização metodológica. $\mathrm{O}$ religioso, porque a presença não mais velada de dissidentes sexuais e de gênero nas religiões tem reconfigurado as próprias experiências espirituais. E, finalmente, o antropológico, pois, afinal, sabemos que muitas pessoas são deixadas de fora dessa categoria, principalmente quando ela se encontra com a teologia. Um exemplo disso seria uma antropologia não somente dos corpos transgêneros, mas produzida por esses corpos/as/es. 
E é justamente em direção à corporeidade e à sexualidade que caminha o debate do princípio pluralista quando propõe suas possíveis aplicações. Segundo Ribeiro (2020), são aplicações do princípio pluralista: o pluralismo religioso, a teologia ecumênica das religiões, os estudos da religião no Brasil, a espiritualidade integral e ecológica, a corporeidade e sexualidade, as dimensões do lúdico e da festividade. Em relação à corporeidade e à sexualidade, afirma Ribeiro (2020) que, “[...] no caso da aplicação do princípio pluralista para a análise teológica de questões de fundo antropológico, reconhecemos que temos no presente momento apenas uma limitada contribuição no campo da pesquisa.” (RIBEIRO, 2020, p. 36).

Existem alguns conceitos fundamentais para o princípio pluralista que podem colaborar em um debate sobre as questões referentes às dissidências sexuais e de gênero, nosso foco de pesquisa e atuação. Mas, para esta resenha optamos em realçar o conceito de entre-lugares. Segundo Ribeiro (2020), o princípio pluralista lança mão do conceito de entre-lugar de Homi Bhabba, como trabalho fronteiriço da cultura, no qual as identidades culturais são forjadas. Ribeiro (2020) explica que “[...] o conceito entre-lugar está relacionado à visão e ao modo como grupos subalternos se posicionam frente ao poder e como realizam estratégias de empoderamento.” (RIBEIRO, 2020, p. 26).

Para nós, esse conceito nos soa familiar como um lugar não somente pelo qual transitamos, mas que acolhemos como morada. Afinal, o que a princípio nos parecia um local de destinação e imposição dos regimes de regramento que nos consideram abjetos, se tornou um local de escolha - escolhemos os entre-lugares em rejeição ao centro hegemônico e tradicional. Percebemos, então, que o princípio pluralista tem uma potência desempoderadora dos regimes de poder, ao se propor ser um princípio que abraça o pluralismo antropológico como esse potente lugar fronteiriço de encontros e transformações. É a partir desse lugar criativo e curativo, que são as fronteiras que habitamos, que se pode apresentar cartografias das relações de algumas religiões brasileiras com as pessoas dissidentes sexuais e de gênero. Afinal, como explica Ribeiro (2020), é aí que está a importância “[...] de interpretações conjuntivas da cultura, que reúnam e articulem as contradições presentes na globalidade, mas, sobretudo, que não desconsiderem as particularidades, as singularidades e a concretude das vivências.” (RIBEIRO, 2020, p. 440).

Segundo Ribeiro (2020), “[...] de nossa parte, enfatizamos que o princípio pluralista possui uma antropologia aberta, marcada por identidades em construção.” (RIBEIRO, 2020, p. 36). E é justamente por tratarmos de identidades em (des)construção, que sabemos que a temática abordada por essa obra estará sempre em transformação. Além disso, 
destacamos que tratamos de temáticas pouco abordadas nas perspectivas pluralistas religiosas.

Ainda que a teologia tenha se debruçado pouco sobre o assunto, sabemos que há uma produção teológica latente nas experiências religiosas a partir dos entre-lugares do cotidiano. Produção teológica que está para além da academia, para além dos tratados teológicos, mas que se encontra nas dinâmicas do cotidiano que atravessam o corpus teológico, permitindo que a vida dinamize as relações com o Sagrado.

Recebido em: 02 set. 2021 Aprovado em: 02 set. 2021 